\title{
ANALISIS USAHA PEMBUATAN GULA MERAH DI KECAMATAN SUKAMAJU
}

\author{
RUSMIATI, SAMSUL BACHRI, RISMAWATI
}

\begin{abstract}
ABSTRAK
Tujuan penelitian adalah untuk mengetahui dan menganalisis usaha pembuatan gula merah di Kecamatan Sukamaju. Penelitian yang dilakukan merupakan penelitian explanatory dan me ggunakan metode survey.

Populasi penelitian adalah pembuat gula yang ada di wilayah Kecamatan Sukamaju Kabupaten Luwu Utara sekaligus di jadikan sebagai sampel dan diperoleh 50 sampel. Metode analisis data yang dipergunakan dalam penelitian ini adalah analisis deskriptif dan Regresi Linier Berganda, diman variabel bebasnya terdiri dari bahan baku dan biaya; variabel dependen produksi gula merah.

Hasil penelitian dengan menggunakan analisis regresi linier berganda menunjukkan bahwa secara bersama-sama variabel bahan baku dan biaya berpengaruh signifikan terhadap produksi gula merah. Sedangkan untuk uji t diketahui bahwa tingkat signifikan untuk masingmasing variabel yaitu (bahan baku =0,000) dan (biaya =0,000). Dari hasil tersebut ke dua variabel dapat membuktikan hipotesis yang menduga bahwa faktor-faktor yang meliputi bahan baku dan biaya berpengaruh positif terhadap produksi gula merah di Kecamatan Sukamaju Diterima atau terbukti kebenarannya.

Kesimpulannya bahwa adanya pengaruh yang signifikan dengan analisis usaha pembuatan gula merah di kecamatan sukamaju Berdasarkan kesimpulan di atas, dikemukakan saran yag ditujukan untuk : (1) pengrajin gula merah di Kecamatan Sukamaju Kabupaten Luwu Utara : dan (2) peneliti lain yang bermaksud melakukan penelitian dengan topik yang mirip.
\end{abstract}

Kata Kunci : bahan baku, biaya, dan produksi gula merah.

\section{Pendahuluan}

\section{Latar Belakang}

Gula merah atau biasa di sebut dengan gula jawa merupakan kebutuhan pokok manusia yang selalu mengalami perubahan yang cenderung meningkat. Peningkatan tersebut terjadi seiring meningkatnya pendapatan penduduk serta semakin banyak industri pangan yang menggunakan gula merah sebagai bahan bakunya.

pada dasarnya kegiatan suatu perusahaan itu tujuannya sama, yaitu memperoleh laba yang maksimal mungkin, tetapi pada kenyataannya hal ini terlepas dari volume produksi yang menjadi kendala dalam meningkatkan laba suatu usaha, karena dengan laba yang meningkat, berarti perusahaan terus maju berkembang. Oleh karena itu, setiap uasaha sangat perlu untuk 
melakukan efesiensi di dalam kegiatan produksi baik produksi berupa jasa atau barang dagangan. Karena produksi menjadi andalan utama selain penjualan untuk memperoleh laba perusahaan.

Saat ini banyak perusahaan yang didirikan, karena tujuan dari perusahaan tersebut yaitu memperoleh laba yang besar. Sehingga menjadi persaingan disebuah bidang usaha, khususnya di Kabupaten Luwu Utara ini. Kabupaten Luwu Utara sebagai salah satu kota yang sedang berkembang di Provinsi Sulawesi Selatan, mendorong minat para pelaku usaha mikro kecil dan menengah untuk menjadikan Kabupaten Luwu Utara sebagai basis ekonomi mikro yang potensial dalam menghasilkan produk.

Namun keberadaan agroindustri ini ternyata belum mampu menjalankan perannya secara optimal. Produsen harus menghabiskan waktu yang cukup lama untuk mengembangkan usahanya ini, bahkan ada dari mereka yang tidak bertahan dalam usaha ini. Faktor yang menyebabkan antara lain modal yang terbatas, pasar yang masih lokal daerah teknologi belum modern.

Saat ini banyak perusahaan yang didirikan, karena tujuan dari perusahaan tersebut yaitu memperoleh laba yang besar. Sehingga menjadi persaingan di sebuah bidang usaha, khususnya di Kabupaten Luwu Utara ini. Kabupaten Luwu Utara sebagai salah satu kota yang sedang berkembang di Provinsi Sulawisi Selatan, minat para pelaku mikro, kecil dan menengah untuk menjadikan Kabupaten Luwu Utara sebagai basis ekinomi mikro yang potensial dalam menghasilkan produk.

Kecamatan Sukamaju Kabupaten Luwu Utara merupkan salah satu pengrajin atau produsen gula merah di Luwu Utara. Hasil perkebunan kelapa yang memiliki nilai ekinomis yang tinggi mendorong masyarakatnya untuk mengelolah hasil perkebunan kelapa untuk di produksi menjadi gula merah.

Faktor-faktor tersebut secara langsung maupun tidak langsung akan berpengaruh pada kualitas maupun kontinyuitas produksi gula merah yang di hasilkan masih rendah sehingga keuntungan yang di peroleh produsen gula merah tidak bisa maksimal. Akan tetapi produsen yang mampu memanfaatkan peluangpeluang ekonomi dan memiliki strategi dalam mengusahakan agroindustri gula merah akan mampu bertahan bahkan dapat meningkatkan pendapatan dan skala usaha. Sebagai barang komsumsi, maka gula merah mempunyai peran dalam sistem pangan manusia. Selain sebagai penyedia rasa manis, gula merah juga merupakan salah satu pemasok kalori, oleh karena itu gula merah banyak di butuhkan oleh manisia untuk 70

di komsumsi. Masalah dalam penelitian ini adalah apakah faktor- faktor yang meliputi bahan baku dan biaya berpengaruh terhadap produksi gula merah di Kecamatan Sukamaju. Tujuan Penelitian ini adalah untuk mengetahui faktor-faktor yang meliputi bahan baku dan biaya berpengaruh tergadap produksi gula merah di Kecamatan Sukamaju.

\section{Metode Penelitian}

Tempat dan waktu penelitian

Lokasi penelitian ini di laksanakan di wilayah Kecamatan Sukamaju dengan \pm 2 bulan setelah proposal mendapat persetujuan. 
Jenis dan sumber data

1. Data Primer

Data primer adalah data yang berisikan fakta-fakta atau keterangan yang secara langsung di peroleh melalui penelitianlapangan dari proyek yang di teliti, data ini kami peroleh melalui wawancara kepada para pembuat gula merah di wilayah Kecamatan Sukamaju, dengan menggunakan daftar pertanyaan yang telah di persiapkan sebelumnya.

2. Data Sekunder

Data sekunder adalah data sejumlah fakta atau keterangan yang di peroleh peneliti secara langsung mauapun tidak langsung melalui bahan-bahan, keterangan-keterangan atau peraturan -peraturan perundang-undangan, arsiparsip, lembaga atau instansi terkait dan sebagainya yang berkaitan dengan masalah yang penulis teliti.

Populasi dan sampel

Populasi pada penelitian ini adalah semua pembuat gula yang ada di wilayah Kecamatan Sukamaju yang berjumlah 100 orang. Sedangkan cara pengambilan sampel dengan metode sampling yaitu di tetapkan $50 \%$ dari jumlah sampel yaitu 50 orang.

Metode pengumpulan data

Untuk memperoleh data-data dalam penelitian ini penulis mempergunakan tekhnik pengumpulan data sebagai: (a) Penelitian lapangan, (b) Observasi sistematik; Observasi ini merupakan pengumpulan data dimana peneliti terjun langsung ke lapangan untuk mengadakan pengamatan dan penelitian terhadap keadaan yang sesungguhnya terjadi, dengan membawa scope observasi secara tegas sesuai dengan tujuan peneliti, (c) Wawancara dan interview; Merupakan mengumpulan data dengan jalan mengadakan tanya jawab secara langsung dengan responden, wawancara yang penulis lakukan adalah dengan menggunakan daftar pertanyaan

yang telah di persiapkan dengan kerangka atau pokok -pokok pertanyaan yang di ajuakn, di mana sebelum di ajukan pertanyaan tersebut bersifat terbuka, artinya responden bebas mengemukakan jawaban asalkan sesuai dengan pertanyaa - pertayaan dan permasalahanpermasalahan yang telah di ajukan. (d) Studi kepustakaan; Merupakan tekhnik pengumpulan data dengan mengumpulkan, membaca dan mengkaji dokumen, buku-buku perpustakaan, peraturan-peraturan perundang-undangan dan bahan pustaka lainya. Baik yang di dapatkan di lokasi maupun tempat lain saat di lakukan penelitian. Metode analisis data

Bertitik tolak pada tujuan kerangaka pikir penelitian seperti telah di kemukakan sebelumnya, tekhnik analisis permasalahan-permasalahan yang terjadi dalam penelitian ini menggunakan pendekatan kuantitatif dengan model regresi linier berganda yang bertujuan atau mengandung maksud untk mengetahui tingkat pengaruh positif dan negatif dari beberapa faktor yang di teliti dan ada kaitannya dengan proses produksi, di mana dalam menganalisis data dapat di formulasikan sebagai berikut:

$$
Y=\alpha+\beta_{1} X_{1}+\beta_{2} X_{2}+e_{i} \text { Di mana: }
$$




$$
\begin{aligned}
& \mathrm{Y}=\text { Produksi Gula Merah } \alpha=\text { Nilai } \\
& \text { Intersepsi (Konstanta) } \beta_{1}-\beta_{4}=\text { Koefisien } \\
& \text { Regresi } \\
& \mathrm{X}_{1} \quad=\text { Bahan Baku } \\
& \mathrm{X}_{2} \quad=\text { Biaya } \\
& \mathrm{e}_{\mathrm{i}} \quad=\text { error (tingkat kesalahan) }
\end{aligned}
$$

\section{Hasil Penelitian Dan Pembahasan}

Penelitian ini di lakukan dengan menyebar kuesioner kepada 50 orang responden pembuat gula yang ada di wilayah Kecamatan Sukamaju Kabupaten Luwu Utara. Keseluruhan kuesioner telah di kembalikan dan terisi dengan benar sesuai dengan kebutuhan penelitian. Jenis penelitian merupakan penelitian penjelasan ( explanatoty research), yamg mencoba untuk menjelaskan hubungan kasual ( sebabakibat) antar variabel independen/ variabel bebas yaitu $\mathrm{X}_{1}$ ( Bahan Baku) dan $\mathrm{X}_{2}$ (Biaya) terhadap variabel dependen/variabel terikat yaitu ( Produksi Gula Merah) Y. Selanjutnya di lakukan analisis Regresi Linier Berganda untuk memperoleh gambaran hubungan kausal - efek antar variabel yang di teliti.

Penentukan Persamaan Regresi

Tabel 4

Hasil Persamaan Regresi

Coefficients

\begin{tabular}{|l|l|l|l|l|l|}
\hline model & \multicolumn{2}{|l|}{$\begin{array}{l}\text { Unstandardized } \\
\text { coeffcients }\end{array}$} & $\begin{array}{l}\text { Standardizer } \\
\text { coeffients }\end{array}$ & T & Sig \\
\cline { 1 - 4 } 1( constan) & B & Std error & Beta & & \\
\cline { 2 - 4 } bahan baku & 8.385 & 1.252 & & 6.695 & 000 \\
biaya & 1.818 & 062 & 1.456 & 29.101 & 000 \\
& -074 & 007 & -531 & -10.603 & 000 \\
\hline
\end{tabular}

a. Dependent variabel : jumlah produksi

Sumber data lampiran 3

$\mathrm{Y}=8.385+1,818 \mathrm{X} 1-0,074 \mathrm{X} 2$

Dimana masing-masing regresi tersebut mempunyai arti sebagai berikut:

$\mathrm{B}_{\mathrm{o}}=8,385$

Konstanta sebesar 8,385 menyatakan bahwa jika variabel independen (Bahan Baku dan Biaya) dianggap konstan, maka rata-rata jumlah produksi gula merah sebesar $8,385 \mathrm{~b}_{1}=1,818$ Bahan Baku.

Koefisien regresi Bahan Baku sebesar satu satuan akan meningkatkan jumlah

Produksi Gula Merah 1,818 kg 
$\mathrm{B}_{2}=(-0,074)$ Biaya

Koefisien regresi Biaya sebesar (-0,074) menyatakan bahwa setiap penambahan Biaya sebesar satu satuan akn menurunkan jumlah Produksi Pula Merah (-0,074).

\section{Koefisien Determinasi}

Analisis ini digunakan untuk mengetahui besarnya proporsi sumbangan dengan variabelvariabel yang terdiri dari variabel independen/variabel bebas yaitu $\mathrm{X}_{1}$ (Bahan Baku) dan $\mathrm{X}_{2}$ (Biaya) terhadap variabel dependen/variabel terikat yaitu (Produksi Gula Merah) Y. Berdasarkan hasil pada lampiran 3 perhitungan di ketahui:

Tabel 5

Koefisien Determinasi/R Square

\begin{tabular}{|l|l|l|l|l|}
\hline Model & R & R Square & $\begin{array}{l}\text { Adjusted } \\
\mathbf{R} \\
\text { Square }\end{array}$ & $\begin{array}{l}\text { Std. Error of } \\
\text { the estimate }\end{array}$ \\
\hline 1 & $991^{\mathrm{a}}$ & 982 & 981 & 74813 \\
\hline
\end{tabular}

Sumber data lampiran 3

Adjusted R Square sebesar 0,981 artinya bahwa variasi perubahan variabel terikat yakni produksi gula merah (Y) sebesar 98,1\% secara bersama-sama disebabkan oleh variabel bebes yang terdiri dari $\mathrm{X}_{1}$ (Bahan Baku) dan $\mathrm{X}_{2}$ (biaya). Sedangakan sisanya sebesar $1,9 \%$ disebabkan oleh variabel lain yang tidak teridentifikasi kedalam model.

Pengujian secara simultan (Uji F)

Pengujian ini dimaksudkan untuk mengetahui bagaimana variabel bebas yang terdiri dari variabel yaitu $\mathrm{X}_{1}$ (bahan baku) dan $\mathrm{X}_{2}$ (biaya) secara bersama-sama beroengaruh terhadap variabel dependen (variabel terikat) yaitu (Produksi Gula Merah) Y.

Adapun langkah-langkah pengujianya adalah:

1) $\mathrm{H}_{\mathrm{o}}: \mathrm{B}_{\mathrm{i}}=0$, Berarti tidak ada pengaruh antara variabel bahan baku dan biaya terhadap produksi gula merah.

2) Level of signifikan pada tingkat $\alpha=5 \%$

$\mathrm{F}_{\text {tabel }}$ dengan tingkat keyakinan $95 \%$ dan df (k-1) dan (n-k)

3) Fhitung $<\mathrm{F}_{\text {tabel }}$ berarti $\mathrm{H}_{\mathrm{o}}$ di terima $\mathrm{H}_{\mathrm{a}}$ ditolak

Fhitung $>\mathrm{F}_{\text {tabel }}$ berarti $\mathrm{H}_{\mathrm{a}}$ diterima $\mathrm{H}_{\mathrm{o}}$ ditolak

Tabel 6

Hasil uji secara simultan (Uji F) Anova

\begin{tabular}{|l|l|l|l|l|l|}
\hline Modal & $\begin{array}{l}\text { Sum of } \\
\text { squares }\end{array}$ & Df & $\begin{array}{l}\text { Mean } \\
\text { square }\end{array}$ & F & Sig \\
\hline
\end{tabular}




\begin{tabular}{|l|l|l|l|l|l|}
\hline $\begin{array}{l}1 \text { regression } \\
\text { residual } \\
\text { total }\end{array}$ & 1412.114 & 2 & 706.057 & 1261.486 & $000 \mathrm{a}$ \\
\hline
\end{tabular}

a.predictors (constant), biaya, bahan baku

b. dependen variabel : jumlah produksi sumber data

lampiran 3

Dari hasil perhitungan diketahui bahwa : Fhitung $=1261,486>$ Ftabel $=2,81$ atau tingkat signifikasi sebesar 0,000 lebih kecil jika dibandingkan dengan tingkat $\alpha=$ $5 \%$ berarti bahwa X 1 (Bahan Baku) dan X2 (Biaya) secara bersama-sama berpengaruh signifikan terhadap variabel dependen (variabel terikat) yaitu (Produksi Gula Merah) Y.

Pengujian Secara Partial (Uji t)

Pengujian secara partial ( uji $-\mathrm{t}$ ) dimaksud untuk mengetahui tingkat signifikan antara variabel terikat secara staistik adalah sebagai berikut :

Tabel 7

Hasil Uji Secara Parsial (Uji t) Coefficients $\alpha$

\begin{tabular}{|c|c|c|c|c|c|}
\hline \multirow[t]{2}{*}{ Model } & \multicolumn{2}{|c|}{$\begin{array}{l}\text { Unstandardized } \\
\text { Coefficients }\end{array}$} & \multirow{2}{*}{$\begin{array}{l}\text { Standardized } \\
\text { coefficients } \\
\text { Beta } \\
\end{array}$} & \multirow[t]{2}{*}{$\mathbf{T}$} & \multirow[t]{2}{*}{ Sig } \\
\hline & B & Std. Error & & & \\
\hline $\begin{array}{l}\text { (Constant) } \\
\text { Bahan Baku } \\
\text { Biaya }\end{array}$ & $\begin{array}{l}8.385 \\
1.818 \\
-074\end{array}$ & $\begin{array}{l}1.252 \\
062 \\
007\end{array}$ & $\begin{array}{l}1.456 \\
-531\end{array}$ & $\begin{array}{l}6.695 \\
29.101 \\
-10.603\end{array}$ & $\begin{array}{l}000 \\
000 \\
000\end{array}$ \\
\hline
\end{tabular}

a Dependent Variabel: Jumlah Produksi

Sumber Data: Lampiran 3

Variabel Bahan Baku (X1).

a. Ho : B1 = 0, Variabel bahan baku tidak berpengaruh terhadap proses produksi (Y). Ha $: \mathrm{B} 1 \neq 0$ Variabel bahan baku berpengaruh terhadap proses produksi (Y). Level Of signifikan pada tingkat $\alpha=5 \%$ ttable pada derajat signifikan dengan pendekatan uji hipotesis dua sisi dan derajat kebebasan $\mathrm{n}-\mathrm{k}$

b. Thitung $<\mathrm{T}$ tabel berarti Ho diterima dan Ha di tolak Thitung $>\mathrm{T}$ tabel berarti Ha diterima dan Ho di tolak

Dari hasil perhitungan di ketahui bahwa : variabel bahan baku (X1) menghasilkan nilai thitung $=29,101>$ ttabel $=2,011$ atau tingkat signifikan sebesar 0,000 lebih kecil jika dibandingkan dengan tingkat $\alpha=5 \%$

Berdasarkan hasil perhitugan tersebut menunjukkan bahwa ada pengaruh yang nyata antara biaya terhadap proses produksi. 


\section{Pembahasan}

Berdasarkan hasil uji $\mathrm{F}$ dalam analisis regresi linear berganda pada penelitian ini diketahui bahwa tingkat signifikan sebesar 0,0000a lebih kecil jika di bandingkan dengan tingkat $\alpha=5 \%$ berarti bahwa semua variabel bebas yang meliputi X1 (Bahan Baku) dan X3 (Biaya) secara bersama-sama mempunyai pengaruh yang signifikan terhadap variabel dependen (variabel terikat) yaitu (Proses Produksi) Y. Dengan demikian, hipotesis penelitian ini yang menduga bahwa faktor-faktor yang meliputi bahan baku dan biaya berpengaruh positif terhadap produksi gula merah di kecamatan sukamaju".adalah terbukti kebenarannya.

Besarnya pengaruh semua faktor-faktor yang meliputi X1 (Bahan Baku) dan X3 (Biaya) secara bersama-sama mempunyai pengaruh yang signifikan terhadap variabel dependen (Variabel terikat) yaitu (Produksi Gula Merah) Y sebesar 0,982 atau 98,2\%. Dengan demikian dapat disimpulkan pula bahwa perubahan volume penjualan dipengaruhi oleh faktor lain secara variabel bebas pada penelitian ini sebesar 0,018 atau $1,8 \%$.

Relatif tingginya pengaruh faktor-faktor yang meliputi X1 (Bahan Baku), dan X2 (Biaya)

\section{5}

secara bersama-sama mempunyai pengaruh yang signifikan terhadap variabel Dependen (variabel terikat) yaitu (Produksi Gula Merah) Y menunjukkan bahwa asumsi pengabaian faktor-faktor lain misalnya distribusi penjualan, nantinya diharapkan pada penelitian berikutnya yang meneliti tentang pengaruh faktor-faktor yang mempengaruhi produksi gula merah perlu juga mengikut sertakan variabel distribusi penjualan.

\section{Penutup}

Kesimpulan penelitian ini adalah: (a) Hasil analisis menunjukkan secara simulutan bahwa adanya pengaruh yang signifikan faktor-faktor variabel independen (variabel bebas) yaitu X1 (Bahan Baku) dan X2 (Biaya) terhadap variabel Dependen/variabel terikat yaitu (produksi gula merah) Y, (b) Variabel bahan baku (X1) yang mempuyai pengaruh paling dominan terhadap kesetiaan konsumen terhadap volume penjualan, (c) Secara simultan ditunjukkan oleh nilai R Square sebear 0,981 atau 98,1\%. Hal ini berarti sekitar 98,1\% variabel produksi gula merah dipengaruhi oleh variabel bebas sedangkan 0,019 atau 1,9\% sisanya disebabkan oleh faktor-faktor lain yang tidak di jelaskan di dalam model (ei). Adapun saran dari penelitian ini adalah: (a) Bagi pengrajin gula merah di Kecamatan Sukamaju Kabupaten Luwu Utara Adapun Variabel-variabel yang mempengaruhi Y (produksi gula merah) yaitu variabel X1 (Bahan Baku), X2 (pengrajin), dan X3 (harga) sudah memiliki efektivitas yang maksimal. Adapun aspek-aspek yang berpengaruh positif dan signifikan terhadap produksi gula merah hendaknya dipertahankan dan dibutuhkan kreatifan dan keinovatifan untuk terus dapat meningkatkan aspek-aspek tersebut, (b) Bagi peneliti lain; Peneliti dapat memasukkan faktor-faktor lain misalnya distribusi penjualan, nantinya diharapkan pada penelitian berikutnya yang meneliti tentang topik yang mirip dengan penelitian ini dapat memberikan tambahan variabel yang mampu mengukur produksi gula merah; Peneliti dapat menggunakan sarana objek penelitian lain dalam hal pengrajin gula merah di Kecamatan Sukamaju Kabupaten Luwu Utara, agar dapat memberikan informasi yang nantinya dapat dijadikan sebagai pembanding dalam 
menentukan seberapa besar pengaruh bahan baku, pengrajin, dan biaya berperan penting dalam meningkatkan produksi gula merah.

\section{Daftar Pustaka}

Ahyari, 2002, Manajemen Produksi, Pengendalian produksi, BPFE, Yogyakarta.

Anonim, 2011, Buku pedoman Penulisan Skripsi, STIE Muhammadiyah, Palopo.

Arikunto, 2006, prosedur Penelitian Suatu Pendekatan Praktek, PT. Rineka Cipta, Jakarta.

Assausari, 2008,Manajemen Produksi dan Operasi, LPFE UI, Jakarta. ,2009, Manajemen

Produksi dan Operasi, Edisi Revisi, LPFE UI, Jakarta.

Ayu Mutiara 2010 Analisis pengaruh Bahan Baku, Bahan Bakar, dan tenaga kerja terhadap produksi tempe di kota semarang. Skripsi program sarjana ilmu ekonomi dan studi pembangunan. Unuversitas di poonegoro. http://eprints.undip.ac.id/22586/1/skripsi.pdf.

Bambang Hermanto. 2011. Pengaruh Biaya Produksi terhadap pendapatan petani kelapa sawit $\begin{array}{lllll}\text { jurnal } & \text { kaltura } & \text { volume } & 12 & \text { No. }\end{array}$ juni.www.umnaw.com/.../1.\%20Bambang\%20Haeranto,\%20SP,\%20Msi.

Ghozali, Imam. 2006. Aplikasi Analisis Multivariate Dengan Program SPSS. Semarang: Badan Pernerbit Universitas diponegoro :19,198.

Handoko, 2000, Manajemen Pemasaran, BPFE, Yogyakarta.

Iskandal, 2003, Pengantar Ekonomi Mikro dan Makro, Glia indonasi, Jakarta

Kusuma, 2000, Pustaka Kusuma Ttingkat Persamaan

76

Produk,http://www.google.co.id//search, (diakses 12 maret 2012).

Santoso, singgih. 2004. SPSS Versi 10.00. Jakarta: PT Gramedia Pustaka Utama.

Sugiarto, 2006, Metode Statistika untuk bisnis dan bisnis dan ekonomi, PT. Gramedia Pustaka Utama, Yogyakarta.

Undang-undang No.20 tahun 2008. Tentang usaha kecil.

Yamit, 2000, Manajemen Kualitas Produk dan Jasa, Ekonisia, Yogyakarta. 
http://gulamerahmb.wordpress.com/2010/08/03/cara-membuatgulamerah/http://tanamanobatherbal.com/2011/05/sejarah-gula-merah/ 